\title{
Economic Performance of Pre-Crops in a Three-Year Rotation Program for Organic Vegetable Production
}

\author{
E. Bilen, C. A. Nazik, M. Unal, M. R. Bteich \\ and L. Al Bitar \\ CIHEAM Mediterranean Agronomic \\ Institute of Bari, 70010 Bari, Italy
}

\author{
U. Aksoy \\ Ege University Faculty of Agriculture \\ Department of Horticulture, 35100 \\ Bornova, Izmir, Turkey
}

Key words: Gross margin, revenue, tomato, zucchini, pepper

\begin{abstract}
A four year experiment is being carried out, at Ege University Department of Horticulture, in which three different pre-crops are tested under an organic management system as compared to fallow. The aim of the experiment is to identify the most suitable rotation program for organic vegetable production in Turkey. Vicia sativa (common vetch), Brassica oleracea var. italica (broccoli), Vicia faba 'Sevilla' (faba bean) and fallow are tested as preceding (winter) crops. During the experiment carried out between 2007 and 2009, the main crops were tomato (2007), zucchini (2008) and pepper (2009). Broccoli represented the farmers' choice as a winter vegetable. Vetch (incorporated) and faba bean (partially harvested and incorporated) were selected as legumes well adapted to the regional conditions. Soil fertility was maintained by incorporation of the crop residues at the end of both cycles and addition of organic-certified commercial compost (Bioaktif) and compost tea during the main cycle. All the management, including disease and pest management, was carried out according to the organic regulations valid in Turkey and the EU. During the production seasons, all variable costs and revenue, during both the pre-crop and main crop cycles, were recorded and gross margin calculated for each treatment. Economic analysis showed that broccoli as a pre-crop required the highest variable costs followed by faba bean, vetch and fallow, in all three years. Total revenue was the highest in plots where broccoli was the pre-crop. It is followed by faba bean plots mostly because higher yields were obtained in main crop plots following faba bean. The least profitable was fallow - main crop rotation. Broccoli plants also have some extra benefits like adding a high amount of biomass to soil and suppressing weed growth due to shading and allelopathic effects.
\end{abstract}

\section{INTRODUCTION}

Turkey is the fourth biggest vegetable producer after China, India and United States and a big exporter of vegetable products (FAOSTAT, 2009). As a Mediterranean country, vegetables are also an important part of the Turkish diet (FAOSTAT, 2009). Vegetable production has higher demands in terms of inputs like pesticides and fertilizers, which creates a risk of contamination of the food and environment, if the production does not take into account proper measures (Tilman et al., 2001; Pimentel, 2005). As an important commodity for export and consumption, intensive use of inputs may also pose threat to human health and to the environment. Organic vegetables are an important option to avoid such risks (Cardelli, et al., 2004). Additionally, there is an increasing market demand for these products (Romesh et al., 2005; Greene and Dimitri, 2009). Many farmers and agricultural professionals, however, are uncertain about the profitability and risks associated with organic vegetable production. 
When organic price premiums are included, net returns from organic systems are higher than conventional systems (Archer, et al., 2007; Delate et al., 2003; Mahoney, et al., 2004; Smith et al., 2004; Clark et al., 1999; Hanson and Musser, 2003; Archer and Kludze, 2006).

In Turkey, vegetable farmers generally produce only one crop (a winter or a summer vegetable) and leave the field empty for the rest of the season which reduces the use efficiency of the agricultural field (Nazik, 2007; Bilen, 2008; Ünal, 2009).

A common research strategy - coordinated by the CIHEAM Mediterranean Agronomic Institute of Bari in the framework of its Master program "Mediterranean Organic Agriculture" - was adopted by four institutes in four Mediterranean countries, Turkey, Italy, Tunisia and Morocco. The research foresees the development of agronomically, ecologically and economically suitable rotation programs. Parallel fouryear rotation programs were initiated in 2006 in 4 countries on an experimental station belonging to the institutions involved. In the second phase of the research, selected models will be tested at farm level.

The aim of this research is to test and finally recommend sustainable rotation models which are economically and technically feasible for Mediterranean conditions and to analyze the most suitable crop rotation model for open field vegetable production under organic management conditions in Izmir, Turkey.

This paper evaluates the three-year economic performance of the tested pre-crops and main crops between 2006 and 2008.

\section{MATERIALS AND METHODS}

\section{Experimental Site}

1. Farm Location and History. The study was carried out at the experimental field of Faculty of Agriculture, Horticulture Department of Ege University in Izmir / TURKEY. The site is $40 \mathrm{~m}$ above the sea level and located at $38^{\circ} 27^{\prime} 15.4^{\prime \prime} \mathrm{N}$ and $27^{\circ} 13^{\prime} 26.3^{\prime \prime} \mathrm{E}$ (GPS, Garmin 12).

Prior to the experiment, the field was a cherry collection orchard. No fertilizers or pesticides were applied to the plot since 2002. The trees were uprooted in 2005 and the long-term experiment was initiated in 2006.

Vicia sativa (common vetch), Brassica oleracea var. italica (broccoli), Vicia faba 'Sevilla' (faba bean) and fallow were tested as preceding (winter) crops for all three years of the experiment. As main crops for which performance was evaluated in this study, three different species were used in the three years of the experiment (2006-2007, 20072008, 2009-2010): tomato, Lycopersicon esculentum L. 'Porsuk' (Nazik, 2007), zucchini, Cucurbita pepo L. 'Beyaz Kabak' (Bilen, 2008) and pepper, Capsicum annum 'Charliston' Yalova-1 (Ünal, 2009), respectively.

2. Climatic Conditions. The region is characterized by a Mediterranean climate with dry summers followed by long rainy seasons. Precipitation in Izmir is distributed as follows: $22 \%$ in spring, $2 \%$ in summer, $21 \%$ in autumn and $55 \%$ in winter. The Turkish State Meteorological Service reports the average rainfall of the last 70 years to be of $689 \mathrm{~mm}$. During the experiment, the recorded values were: $745 \mathrm{~mm}$ in $2006,478 \mathrm{~mm}$ in 2007 , $427.3 \mathrm{~mm}$ in 2008 and $682.3 \mathrm{~mm}$ until the end of August, 2009. 


\section{Pre-crops}

Three pre-crops were tested: Vicia faba 'Sevilla' (faba bean), as a commercial legume, Vicia sativa (common vetch), as an incorporated legume and Brassica oleracea var. italica (broccoli), as farmers' choice. Broccoli and faba bean (in 2008 and 2009) were harvested and marketed. The fourth variable was fallow where weeds were incorporated. Natural vegetation in fallow subplots, vetch and broccoli were cut before the incorporation to improve the degradation process.

\section{Main-crops}

After the end of the pre-crop production, plant residues were incorporated into the soil. After allowing for degradation of the pre-crops, main-crops (tomato, zucchini and pepper) were planted to the same plots as summer vegetables.

\section{Fertilization program}

Nutrition needs of the plants were maintained by applying certified organic commercial compost (Bioaktif) both as compost and compost tea. The composition of compost (Bioaktif) is detailed in Table 1. Compost tea was prepared from commercial compost under aerobic conditions in plastic tanks in order to avoid air contamination from insects or dust. Major macro nutrient content of the applied compost tea is $\mathrm{N} 0.14 \%, \mathrm{P}$ $43.1 \mathrm{ppm}, \mathrm{K} 1480 \mathrm{ppm}$ and $\mathrm{Mg} 81.3 \mathrm{ppm}$.

\section{Weed, pest and disease management}

Weed control was done manually, by hoeing, to minimize adverse effects on soil fauna, and to minimize carbon dioxide emissions. For pest and disease control, preparations permitted in organic agriculture (EC 2092/91 and Turkish Regulation on Organic Farming, 2005) were used when necessary.

\section{Economic analysis}

Economic evaluation associated with the rotation programs was performed by calculating the Gross Margin (GM) for each of the four tested treatments (pre-crops). Each calculated value represents the average of data collected from four replicates for each treatment. Gross margin was used instead of whole-farm budget calculation due to difficulties related to the calculation of fixed costs under experimental conditions.

Gross margin is calculated with the average of variable costs (input, labor and machine costs) and gross income (output, yield) for each treatment, according to the following equation (Kay and Edwards, 1999):

$\mathrm{GM}=$ gross revenue (total gross income) - total variable costs.

Data collection has been carried out throughout the experimental period, and records have been taken for all the agronomic operations.

\section{Statistical analysis}

Analysis of variance was done using the statistical analysis program SPSS V16.

\section{RESULTS}

For the total course of the three-year trial, total gross margin was the highest in broccoli plots with $62.085 €$.ha $^{-1}$ (Table 2). During the first and second years, the highest gross margin is obtained in broccoli-tomato or zucchini with $19.562 €$. ha $^{-1}$ and 23.328 
$€ . \mathrm{ha}^{-1}$, respectively. There were no significant differences between treatments in the first year whereas pre-crops exerted significant $(\mathrm{P}<0.01)$ effect in the second year (Tables 3 and 4). In the third year, faba bean-pepper gave the highest gross margin with 24.503 $€ . \mathrm{ha}^{-1}$, which is related to the high revenues with faba bean and lower variable costs (Table 5).

As seen in Table 2, the lowest gross margin were obtained in the sub-plots where main crop followed fallow (total gross margin for three years was $35.278 €$.ha $^{-1}$ ). During the second year of the experiment, fallow was in the same statistical group as faba bean and vetch. On the third year, and on the total of three years, fallow was in the same group as vetch.

As detailed in Table 4, revenue from pre-crops varied according to the climatic conditions and, more importantly, to the time constraints for the sowing/transplanting of the main crop. Broccoli obtained the highest revenue among pre-crops, and it performed the best in the third year of the experiment compared to the other years.

Revenue obtained from main crops was not affected significantly by the pre-crops during the first two years of the experiment and as the total revenue of all three years. However, the third year cycle showed significant $(\mathrm{P}<0.01)$ differences. Pepper after faba bean obtained the highest revenue $\left(14.064 € . \mathrm{ha}^{-1}\right)$ and all the other treatments resulted in lower revenue and fell into the same statistical group. This result appears to be related to the lower variable costs and higher pod yield from faba bean, compared to earlier years, and higher revenue from pepper as the main crop after faba bean in the rotation (Table 5).

The highest total variable costs were obtained in broccoli-main-crop rotations. This is primarily due to higher costs of propagation material and harvest labor. The high total variable costs were covered by high revenue obtained by marketing the harvested broccoli (Table 3). The economic analysis of the pre-crops and main crops tested in the three years showed that the most profitable rotations were summer vegetables as main crops after broccoli.

\section{DISCUSSION}

Since rotation with broccoli and following summer vegetables allow for two commercial crops per year, this combination resulted in higher income for the first two years of the experiment. This rotation program also reduces the risks of price fluctuations or changing market demands due to two consecutive crops. For the third year, pods were harvested and marketed from faba bean plots, as well. Gross margin obtained from faba bean was higher than broccoli, mainly due to lower variable costs.

Labor costs considered in the analysis were relevant to the Izmir region in Turkey. But as the experimental fields were small, most of the operations in the experiment were carried out with hand labor, increasing variable costs. Under real farm conditions or at larger scale farms, some of these operations can be done with the use of machinery, which will reduce variable costs. However, this impact may not affect the relative performance of the tested pre-crops.

Results suggest that growing pre-crops only for higher revenue, rather than soil building, may offer economic advantages even in the short term. Broccoli had the highest variable costs and highest risk among the tested pre-crops. As observed in the third year of the experiment, rotations with cover crops as vetch may become more profitable under the same yearly conditions. Our results are consistent with those from Cavigelli, et al., 2009. The least profitable rotation plan was fallow after summer vegetables as main 
crops. This suggests that leaving the field empty for the winter season - like most of the Turkish farmers do - is not economically sound.

During tomato and zucchini production period, pre-crops had no effect on revenue from main crops but during pepper production period, pre-crops exerted significant effects. Pepper revenue was the highest after faba bean and the second highest after fallow, as pre-crops.

It is important to note that there are often marketing and post-harvest costs and risks associated with obtaining organic price premiums that are not accounted for in this study. These costs include time involved in certifying a farm, identifying, contacting and developing a relationship with buyers, and drawing up the contracts.

As a conclusion, broccoli-tomato and broccoli-zucchini rotations were the best performing choice among those tested for the first two years, but in the third year, faba bean was the best choice as a pre-crop. If the climatic conditions allow timely planting, rapid plant growth and complete harvest of pods from faba bean, it is recommended as a soil building crop. With lower variable costs it is the best pre-crop in a rotation program with summer vegetables. However further studies may be necessary to assess long-term performance.

\section{Literature cited}

FAOSTAT. 2009. Retrieved May 7, 2010, from Food and Agriculture Organization of the United Nations: http://faostat.fao.org/

Archer, D. and Kludze, H. 2006. Transition to organic cropping systems under risk. In Proceedings of the American Agricultural Economics Association Annual Meeting, (pp. 1-24).

Archer, D., Jaradat, A., Johnson, J.-F., Weyers, S., Gesch, R., Forcella, F., Kludze, H. K. 2007. Crop productivity and economics during the transition to alternative cropping systems. Agronomy Journal (99), 1538-1547.

Bilen, E. 2008. Evaluation of pre-crops and fertilization on organic zucchini under Mediterranean conditions: case of Turkey. Master Thesis, MAIB, Mediterranian Agronomic Institute, Bari.

Cardelli, R., Levi-Minzi, R., Saviozzi, A., nd Riffaldi, R. 2004. Organically and conventionally managed soils: biochemical characteristics. Journal of Sustainable Agriculture (25), 63 - 74.

Cavigelli, M. A., Hima, B. L., Hanson, J. C., Teasdale, J. R. and Conklin, A. E. 2009. Long-term economic performance of organic and conventional field crops in the midAtlantic region. Renewable Agriculture and Food Systems, 24(2), 102-119.

Clark, S., Klonsky, K., Livingston, P. and Temple, S. 1999. Crop yield and economic comparisons of organic, low-input, and conventional farming systems in California's Sacramento Valley. American Journal of Alternative Agriculture (14), 109-121.

Delate, K., Duffy, M., Chase, C., Holste, A., Friedrich, H. and Wantate, N. 2003. An economic comparison of organic and conventional grain crops in a long-term agroecological research (LTAR) site in Iowa. American Journal of Alternative Agriculture (18), 59-69.

Greene, C. and Dimitri, C. 2009. Organic Agriculture: Organic Market Overview. Retrieved June 16, 2010, from USDA: Economic Research Service: http://www.ers.usda.gov/briefing/organic/demand.htm 
Hanson, J. and Musser, W. 2003. An economic evaluation of an organic grain rotation with regards to profit and risk. Economics University of Maryland, Department of Agricultural and Resource. College Park.

Mahoney, P., Olson, K., Porter, P., Huggins, D., Perillo, C. and Crookston, R. 2004. Profitability of organic cropping systems in southwestern Minnesota. Renewable Agriculture and Food Systems (19), 35-46.

Nazik, C. A. 2007. Effect of rotation and fertilization on tomato in the Mediterranean organic farming system: case of Turkey. Master Thesis, IAMB, Mediterranean organic agriculture, Bari.

Pimentel, D. 2005. Environmental and economic costs of the application of pesticides primarily in the United States. Environment, Development, and Sustainability (7), 229 $-252$.

Reganold, J. P., Glover, J. D., Andrews, P. K. and Hinman, H. R. 2001. Sustainability of three apple production systems. Letters to Nature, 926-930.

Romesh, P., Singh, M. and Subbarao, A. 2005. Organic farming: its relevance to the Indian context. Current Science (88), 561-568.

Smith, E., Clapperton, M. and Blackshaw, R. 2004. Profitability and risk of organic production systems in the northern Great Plains. Renewable Agriculture and Food Systems (19), 152-158.

Tilman, D., Fargione, J., Wolff, B., D’Antonio, C. and Dobson, A. 2001. Forecasting agriculturally driven global environmental change. Science (292), 281-284.

Ünal, M. 2009. Evaluation of pre-crops and fertilization on organic pepper production under Mediterranean conditions: case of Turkey. Master Thesis, IAMB, Mediterranean organic agriculture, Bari.

\section{Tables}

Table 1. Minimum nutrient content of organic compost (Bioaktif) produced by Camli Besi (Izmir, Turkey) and certified by ECOCERT.

\begin{tabular}{lc}
\hline Composition & Concentration/Value \\
\hline Total nitrogen & $3.5 \%$ \\
Organic nitrogen & $3 \%$ \\
Total $\mathrm{P}_{2} \mathrm{O}_{5}$ & $3 \%$ \\
Total soluble $\mathrm{K}_{2} \mathrm{O}$ & $2.5 \%$ \\
Total organic matter & $60 \%$ \\
Humic+Fulvic acids & $25 \%$ \\
Humidity & $20 \%$ \\
pH & 8 \\
\hline
\end{tabular}

Table 2. Total gross margin $\left(€ . \mathrm{ha}^{-1}\right)$

\begin{tabular}{lcccc}
\hline \multicolumn{1}{c}{ Pre-Crop } & $2006-2007$ & $2007-2008$ & $2008-2009$ & Total \\
\hline Broccoli & 19562 & $23328 \mathrm{a}$ & $19196 \mathrm{~b}$ & $62085 \mathrm{a}$ \\
Faba Bean & 15792 & $15531 \mathrm{~b}$ & $24503 \mathrm{a}$ & $55826 \mathrm{a}$ \\
Vetch & 17001 & $17162 \mathrm{~b}$ & $2835 \mathrm{c}$ & $36998 \mathrm{~b}$ \\
Fallow & 17644 & $15580 \mathrm{~b}$ & $2055 \mathrm{c}$ & $35278 \mathrm{~b}$ \\
Mean & 17500 & 17900 & 12147 & 47547 \\
\hline
\end{tabular}




\begin{tabular}{lllll}
\hline LSD & $0.424 \mathrm{~ns}$ & $10.868^{* *}$ & $162.641^{* *}$ & $17.986^{* *}$
\end{tabular}
ns indicates non significance, $*$ and $* *$ indicate significance at $\mathrm{P}<0.05$ and $\mathrm{P}<0.01$ respectively.

Table 3. Variable costs $\left(€ \cdot \mathrm{ha}^{-1}\right)$

\begin{tabular}{|c|c|c|c|c|}
\hline Pre-Crop & $2006-2007$ & $2007-2008$ & $2008-2009$ & Total \\
\hline \multicolumn{5}{|c|}{ Variable costs for winter pre-crops } \\
\hline Broccoli & 11364 & 10741 & 11268 & 33372 \\
\hline Faba Bean & 3238 & 2486 & 2404 & 8127 \\
\hline Vetch & 3454 & 1374 & 1542 & 6370 \\
\hline Fallow & 1161 & 250 & 406 & 1817 \\
\hline \multicolumn{5}{|c|}{ Variable costs for main crops (summer vegetables following four pre-crops) } \\
\hline Broccoli & 10417 & 6018 & 6211 & 22646 \\
\hline Faba Bean & 10394 & 5499 & 6266 & 22159 \\
\hline Vetch & 10363 & 5311 & 6234 & 21908 \\
\hline Fallow & 10348 & 5458 & 6243 & 22048 \\
\hline \multicolumn{5}{|c|}{ Total Variable Costs } \\
\hline Broccoli & 21780 & 16759 & 17479 & 56018 \\
\hline Faba Bean & 13601 & 7984 & 8670 & 30255 \\
\hline Vetch & 13847 & 6685 & 7776 & 28309 \\
\hline Fallow & 11509 & 5708 & 5708 & 22925 \\
\hline
\end{tabular}

Table 4. Revenue obtained from pre-crops $\left(€ . \mathrm{ha}^{-1}\right)$

\begin{tabular}{lcccc}
\hline \multicolumn{1}{c}{ Pre-Crop } & $2006-2007$ & $2007-2008$ & $2008-2009$ & Total \\
\hline Broccoli & 8168 & 16473 & 27033 & 51673 \\
Faba Bean & 0 & 575 & 19108 & 19683 \\
Vetch & 0 & 0 & 0 & 0 \\
Fallow & 0 & 0 & 0 & 0 \\
\hline
\end{tabular}

Table 5. Revenue obtained from main crops $\left(€ \cdot\right.$ ha $\left.^{-1}\right)$

\begin{tabular}{lcccc}
\hline \multicolumn{1}{c}{ Pre-Crop } & 2007 (Tomato) & 2008 (Zucchini) & 2009 (Pepper) & Total \\
\hline Broccoli & 33175 & 23614 & $9642 \mathrm{~b}$ & 66431 \\
Faba Bean & 29393 & 22940 & $14064 \mathrm{a}$ & 66398 \\
Vetch & 30849 & 23848 & $10611 \mathrm{~b}$ & 65307 \\
Fallow & 29153 & 21288 & $8703 \mathrm{~b}$ & 59143 \\
Mean & 30642 & 22922 & 10755 & 64320 \\
LSD & $0.584 \mathrm{~ns}$ & $1.062 \mathrm{~ns}$ & $6.830 * *$ & $1.213 \mathrm{~ns}$ \\
\hline
\end{tabular}

ns indicates non significance, ${ }^{*}$ and $* *$ indicate significance at $\mathrm{P}<0.05$ and $\mathrm{P}<0.01$ respectively. 